\title{
An overview of zinc and its importance in dermatology- Part I: Importance and function of zinc in human beings
}

\author{
Nooshin Bagherani ${ }^{*}$ and Bruce R Smoller ${ }^{2}$ \\ ${ }^{1}$ Dermatologist at Dr. Nooshin Bagheran's office, Taha Physicians' building, P.O. Box: 6414715878, Khoramshahr, Khuzestan Province, Iran \\ ${ }^{2}$ Professor and Chair, Department of Pathology, Professor, Department of Dermatology, University of Rochester, School of Medicine and Dentistry, USA
}

\begin{abstract}
Zinc is an essential trace element important for a large number of structural proteins, enzymatic processes and transcription factors. It plays main roles in the cellmediated immunity, bone formation, tissue growth, brain function, growth of the fetus and child. It also has roles in pathogenesis of some dermatological disorders.

In this article, the importance of zinc in human biology and physiology, its pharmacokinetics, causes and manifestations of its deficiency and excess, its therapeutic roles, side effects of zinc supplements and ways for its prevention and treatment have been described.
\end{abstract}

\section{Introduction}

In human beings, zinc $(\mathrm{Zn})$ constitutes less than $0.005 \%$ of total body weight, and is present in all types of cells [1]. It is an essential trace element important for a large number of structural proteins, enzymatic processes and transcription factors [2]. $\mathrm{Zn}$ is important for the cell growth, development, and differentiation [3].

In the world, the prevalence of $\mathrm{Zn}$ deficiency is estimated at more than $20 \%[2,4]$. In one study by second National Health and Nutrition Examination Survey in the USA, the prevalence of $\mathrm{Zn}$ deficiency was estimated 2-3\% [5]. Nutritional Zn deficiency affects over 2 billion people in developing countries $[2,3]$, whereas a considerable proportion of the western population is at risk of marginal $\mathrm{Zn}$ deficiency [3]. It appears that $10 \%$ of the US population consumes less than half the recommended level of $\mathrm{Zn}$ and is at risk of its deficiency [6].

In this article, we collected and summarized the appropriate manuscripts and papers regarding the importance of $\mathrm{Zn}$ and its pharmacokinetics in human beings, causes and manifestations of its deficiency and excess, its therapeutic roles, side effects of $\mathrm{Zn}$ supplements and ways for its prevention and treatment.

\section{History}

From 3000 BC, people have understood the importance of nutrition and nutritional supplements in wound healing. Hippocrates, the father of modern-day medicine believed that good health could be achieved through nutrition [7]. Historically, the $\mathrm{Zn}$ salts such as $\mathrm{Zn}$ oxide or calamine were applied topically to facilitate wound healing for more than 3000 years [1]. For the first time, the importance of the role of $\mathrm{Zn}$ in the development of organisms was reported in 1869, when it was shown to be required for the growth of Aspergillus niger [2,1].

In the early 1900s when advances in biochemistry appeared, many of the essential constituents of nutrition were introduced. These advances led to the discovery of $\mathrm{Zn}$, vitamin $\mathrm{C}$, and many other essential components [7]. Until the mid $20^{\text {th }}$ century, the importance of $\mathrm{Zn}$ in the growth and development of mammals was not recognized. Since that time, $\mathrm{Zn}$ deficiency has been implicated as a cause for a variety of disorders [2]. In 1973, the association between $\mathrm{Zn}$ deficiency and acrodermatitis entropathica (AE) was discovered [8].

\section{Importance and function of zinc}

$\mathrm{Zn}$ is a metal moiety of many enzymes and is essential for normal cellular functions. It has important roles in cell-mediated immunity, bone formation, tissue growth [9], brain function, and growth of the fetus and child [10]. It also plays a role in sperm maturation and motility [11-13]. Conversely, in an in vitro study, Kappus and Reinhold showed that the addition of high doses of heavy metal ion of the $\mathrm{Zn}$ to cultured keratinocytes was cytotoxic to the cells [14]. Zn is effective in liver function and regeneration $[2,15]$. On the other hand, the liver plays an important role in the $\mathrm{Zn}$ homeostasis [2]. Zn has antibacterial activity [16]. It can inhibit the coagulation of plasma by staphylococcus aureus cells $[17,18]$, and also suppress the attachment of this bacterium to coverslips [18]. The functions of $\mathrm{Zn}$ in human beings can summarily be divided into three categories: catalytic, structural, and regulatory $[2,19]$.

In the catalytic role, $\mathrm{Zn}$ is a critical component of hundreds of the metalloenzymes $[2,8,20]$, such as alkaline phosphatase, carbonic anhydrase, pancreatic carboxypeptidases, RNA polymerases [2], alcohol dehydrogenase [2,9], DNA and RNA nucleotidyl transferases, glutamic, lactic and malic dehydrogenase and $\delta$-aminolevulinic acid dehydratase [9].

In the structural role, $\mathrm{Zn}$ coordinates with certain protein domains, resulting in protein folding and producing structures such as "Zn

Correspondence to: Nooshin Bagherani, Dermatologist at Dr. Nooshin Bagheran's office, Taha Physicians' building, P.O.Box: 6414715878, Khoramshahr, Khuzestan Province, Iran; E-mail: nooshinbagherani@yahoo.com

Key words: zinc, function, pharmacokinetic

Received: June 27, 2016; Accepted: July 11, 2016; Published: July 14, 2016 
fingers" [2,20]. Zacl is a Zn finger transcription factor that functions as a potential tumor suppressor gene and has anti-proliferative activity. It is expressed in the nervous system, myocardium, skeletal muscle, and basal aspect of the stratified embryonic epithelia. In addition, Tsuda et al showed that the Zac1 was a potential regulatory gene, effective in chondrogenic differentiation [21]. Basonuclin is another example of the Zn finger proteins, found in the various stratified squamous epithelia in epidermis, esophagus, cornea [22], spermatozoa and oocytes [23]. This protein possibly plays roles in cell proliferation [22], spermatozoa and oocyte differentiation and the early development of an embryo [23].

In the regulatory role, $\mathrm{Zn}$ is essential for the regulation of a number of biologic processes such as gene regulation $[2,19]$. For example, MMP-19 is a member of a large family of the $\mathrm{Zn}$-dependent proteolytic enzymes, most of which are associated with cancer growth and metastasis [24]. In addition, $\mathrm{Zn}$, via regulating of the metallothionein expression, is effective in the intracellular $\mathrm{Zn}$ compartmentalization $[2,25]$ and antioxidant function $[2,26,27]$.

$\mathrm{Zn}$ is also involved in stabilizing the structure and function of over 300 different enzymes $[3,10,16]$. Hence, this element has considerable effects on nearly all aspects of the metabolism that takes place in the organs of the humans' body, especially the skin and hair [9]. $\mathrm{Zn}$ is required for the structural integrity and binding to DNA in more than 2,000 transcription factors regulating the gene expression [3].
The following summarizes the most important roles of $\mathrm{Zn}$ in the immunity and dermatological fields:

\section{The role of zinc in immunity}

$\mathrm{Zn}$ is essential in both cell-mediated and humoral immunity [2]. Its role in the cellular mediators of innate immunity is with phagocytoses by macrophages and neutrophils, natural killer cell activities, delayed hypersensitivity reactions, generation of oxidative burst, cytokine production, and complement activity. Among these, the importance of $\mathrm{Zn}$ on the T lymphocytes is the most [2,28]. Zn deficiency downregulates the T-helper1, whereas it up-regulates theT-helper2 response $[2,3]$. This imbalance in T-helper1/T-helper2 ratio predisposes patients to infections [2].

$\mathrm{Zn}$ acts as an antioxidant [2,8,29], protecting cells from the damaging effects of oxygen radicals produced as a byproduct of immune activation [2,29]. In addition, it is effective in the regulation of metallothionein, which has antioxidant activity $[2,30]$.

Yanagi et al., showed that $\mathrm{Zn}$ in the peripheral blood of $\mathrm{Zn}$-allergic patients induces the peripheral blood mononuclear cells to produce increased macrophage migration inhibitory factor (MIF) levels, which can result in systemic contact dermatitis [31].

The role of $\mathrm{Zn}$ in human immunity has been summarized in Scheme 1.

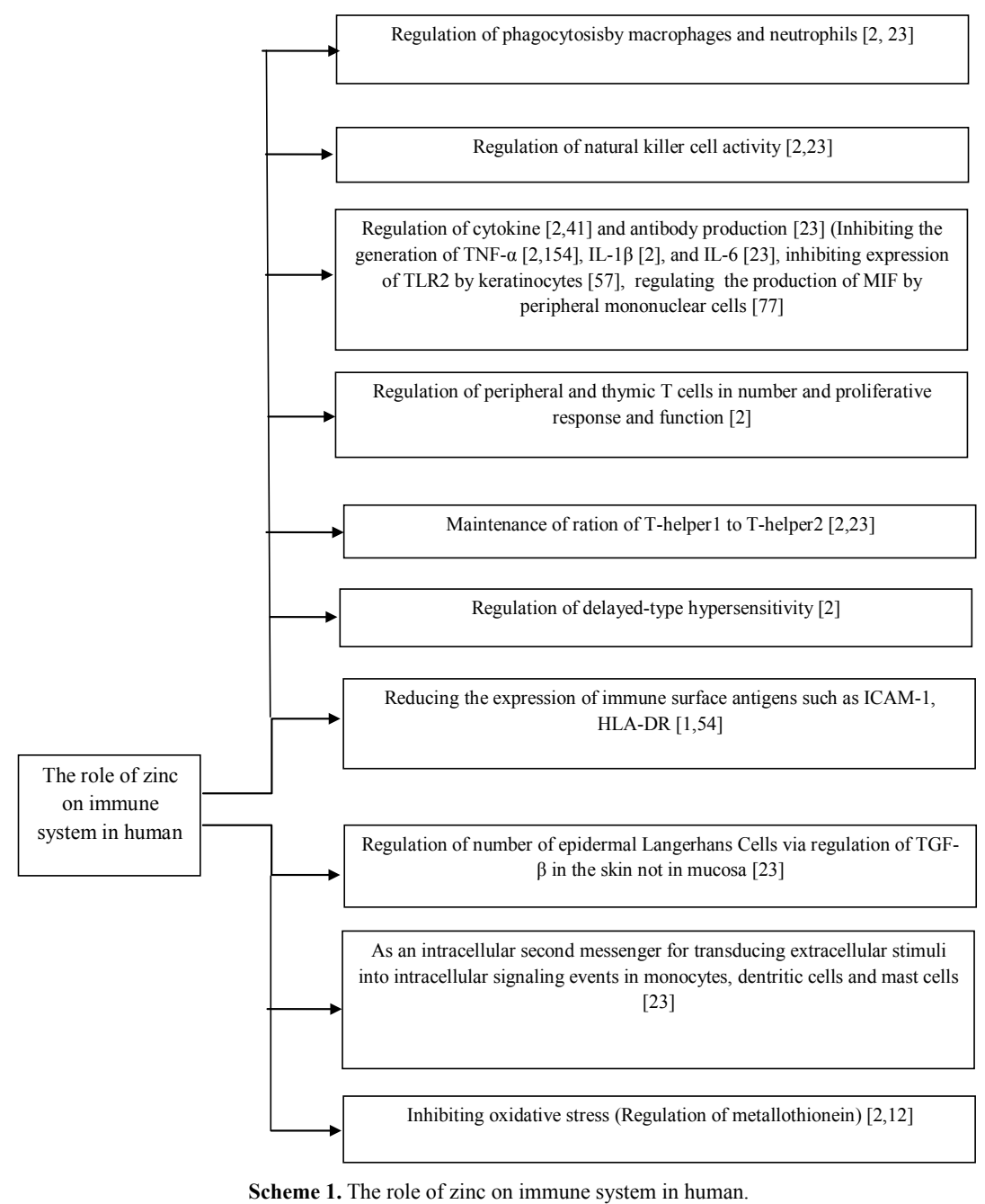




\section{The role of zinc in dermatology}

$\mathrm{Zn}$ and iron are the well-known trace elements associated with the hair growth [34,35]. $\mathrm{Zn}$ is involved in important functional activities in the hair follicles [9]. In addition, it potently inhibits hair follicle regression and accelerates hair follicle recovery $[9,36,37]$.

Chodorowska et al., examined and compared $\mathrm{Zn}$ contents of hair and serum in 2 groups of patients, one with acne phlegmonosa and another group with alopecia areata. Their study showed that in both groups, there was correlation between the $\mathrm{Zn}$ levels in the hair and serum with the alkaline phosphatase activity in the serum [38].

$\mathrm{Zn}$, in combination with other micronutrients such as copper $(\mathrm{Cu})$, cobalt, nickel, iron, manganese, and calcium, has an important role in the process of melanogenesis [39]. In vitro studies have shown that the $\mathrm{Zn}$ cations modulate melanogenesis. Indeed, $\mathrm{Zn}$ inhibits tyrosinase and glutathione reductase, but also increases the activity of dopachrome tautomerase (tyrosinase-related protein-2) and has agonistic effects on the melanocortin receptor signaling in vitro; hence, the final effect of $\mathrm{Zn}$ on the melanogenesis is not identified in vivo. Plonka et al. conducted a study on mice for assessing the effect of oral $\mathrm{Zn}$ on the melanogenesis in vivo. Their study showed that high-dose of the oral $\mathrm{Zn}$ was a potent down-regulator of the eumelanin content in murine hair shafts. On the other hand, they also revealed that the $\mathrm{Zn}$ was not able to switch from the eumelanogenesis to phaeomelanogenesis. This result can be useful for the rapid, qualitative and quantitative monitoring of the hair pigmentation changes [40].

Some studies have shown that the $\mathrm{Cu} / \mathrm{Zn}$ ratio in each skin disease reflects the severity of the progress [41]. This theory can be used for planning more robust studies on diagnosing skin cancers and evaluating their progress.

\section{Absorption, dissemination and excretion of the zinc in human}

In adults, the body contains about 2 grams of $\mathrm{Zn}, 20 \%$ of which is in the skin and hair [42]. The homeostasis of $\mathrm{Zn}$ is highly regulated by the gastrointestinal tract. For this regulation, it is required that the multiple $\mathrm{Zn}$ transporters work in coordination (2). The majority of $\mathrm{Zn}$ is absorbed in the small intestine, especially in the distal duodenum and proximal jejunum [1]. The gastric acidity enhances its absorption [2]. The liver plays an important role in its homeostasis [2]. Maximum concentration of $\mathrm{Zn}$ is reached after 2 to 3 hours of intake [8].

All of the $\mathrm{Zn}$ transporters have trans-membrane domains and are encoded by 2 solute-linked carrier (SLC) gene families. In humans, there are $24 \mathrm{Zn}$ transporters: 9 ZnT (SLC30) and 15 Zip (SLC39) transporters. While the $\mathrm{ZnT}$ transporters decrease the intracellular $\mathrm{Zn}$ concentrations via promoting either the $\mathrm{Zn}$ efflux from cells or $\mathrm{Zn}$ movement into the cellular vesicles, the Zip transporters increase the intracellular $\mathrm{Zn}$ concentration via stimulating either the $\mathrm{Zn}$ influx into the cells or intracellular vesicular release of $\mathrm{Zn}$ [2]. The acrodermatitis entropathica is a rare autosomal recessive disease, in which there is a genetic defect of the synthesis, structure, or function of $\mathrm{Zn}$ binding ligands normally present in the intestine [43].

The S100A9 and S100A8 are calcium (Ca)- and $\mathrm{Zn}$ - binding proteins, respectively. They also play important roles in both $\mathrm{Ca}$ signaling and $\mathrm{Zn}$ homeostasis. These proteins are abundant in the myeloid cells [44].

$\mathrm{Zn}$ absorption rate is controlled by the transport velocity and dietary $\mathrm{Zn}$ intake; so, with depletion of the $\mathrm{Zn}$, the transport velocity increases, and with low dietary intake of $\mathrm{Zn}$, the transporter expression in the small intestine increases, resulting in the increased intestinal $\mathrm{Zn}$ absorption and decreased intestinal loss of $\mathrm{Zn}$. Dietary $\mathrm{Zn}$ binds strongly to proteins near the natural $\mathrm{PH}$ [2]. Thus, its bioavailability varies widely between its different sources, but is about $20 \%$ to $30 \%$ [1]. For example, higher protein intake results in lower bioavailability of $\mathrm{Zn}$ and subsequent decreased $\mathrm{Zn}$ absorption [2]. On the other hand, animal and seafood proteins are rich in $\mathrm{Zn}[8,28]$.

In animals, addition of low doses of prednisolone or prednisone to diet or concomitant supplementation with essential fatty acids can aid the gastrointestinal absorption of $\mathrm{Zn}$, resulting in the increased bioavailability [45].

The majority of body $\mathrm{Zn}$ is stored in the skeletal muscles and bones $[1,2,8]$. Of the remainder, $11 \%$ is stored in the liver and skin, and $0.1 \%$ is found in the plasma. The plasma $\mathrm{Zn}$ concentration is tightly regulated in the range of $10-15 \mu \mathrm{mol} / \mathrm{l}$ [2] or $70-110 \mu \mathrm{g} / \mathrm{dl}[28]$, and fluctuations in the $\mathrm{Zn}$ intake don't effect on this concentration, unless these fluctuations are severe or prolonged. About $80 \%$ of the plasma $\mathrm{Zn}$ is bound to albumin [2].

$\mathrm{Zn}$ is mainly excreted in the feces; hence, the regulation of fecal losses is important in the $\mathrm{Zn}$ homoeostasis. Small amounts of this element are lost in the urine and perspiration [1]. The $\mathrm{Zn}$ value eliminated via the urine is about $300-700 \mu$ g during 24 hours [46].

Topical forms of $\mathrm{Zn}$ have been assessed for percutaneous absorption and cutaneous bioavailability [47]. In an in vitro study, Priot et al showed that $\mathrm{Zn}$ absorption was poor through normal human skin independent of the vehicle used [48]. In another study, Priot et al compared the percutaneous absorption of $\mathrm{Zn}$ from ointments containing $\mathrm{Zn}$ 2-pyrrolidone 5-carboxylate, $\mathrm{Zn}$ oxide, and $\mathrm{Zn}$ sulphate. This study showed that the percutaneous absorption of $\mathrm{Zn}$ from $\mathrm{Zn}$ 2-pyrrolidone 5-carboxylate- containing emulsion was more than from the two others ones. Formulations used in this study increased the $\mathrm{Zn}$ concentration in the whole skin and epidermis [47].

\section{Conditions resulting to the zinc deficiency}

The majority of $\mathrm{Zn}$ loss occurs in the intestine from pancreatic secretions, which varies from $27-90 \mu \mathrm{mol} / \mathrm{day}[2,49]$. The urinary loss of $\mathrm{Zn}$ is lower, and the kidneys reabsorb the filtered $\mathrm{Zn}$ with estimated loss of 8-11 $\mu \mathrm{mol} /$ day. In addition, $\mathrm{Zn}$ loss also occurs via shedding of the epithelial cells, sweat, semen, hair and bleeding during menstruation [2].

In full-term infants, the vast majority of $\mathrm{Zn}$ is stored during the third trimester of pregnancy; hence, the total $\mathrm{Zn}$ stores, especially hepatic stores at birth, are lower in the premature than in full-term infants [10].

The $\mathrm{Zn}$ deficiency can be inherited or acquired $[2,3,10]$. Acrodermatitis entropathica is an autosomal recessive inherited disease resulting from a mutation in the Zip4 transporter $[2,50]$. This disorder is a rare condition related to poor absorption of the $\mathrm{Zn} \mathrm{[10].}$

According to the recommended regimen by the WHO, dietary intake of $\mathrm{Zn}$ is enough to maintain $\mathrm{Zn}$ levels within a normal range, except if there is abnormality in the gastrointestinal or urinary losses [10]. The causes of acquired $\mathrm{Zn}$ deficiency include in:

1. Nutritional $\mathrm{Zn}$ deficiency secondary to inadequate dietary intake and malnutrition [2,51] 


\section{Lack of intake of animal foods [2]}

3. Reduced bioavailability of Zn secondary to the high dietary intake of phytate $[1,2,8,28]$, tetracycline, penicillin, corticosteroids, high doses of iron and $\mathrm{Ca}$, oral contraceptives, and tanino $[8,28]$

4. Receiving total parenteral nutrition without any supplementation of $\mathrm{Zn}[2,28,51,46]$

5. Excessive alcohol use $[2,3,8,28]$

6. Following penicillamine therapy [2]

7. Gastrointestinal affections and malabsorption syndromes $[2,3,28]$

8. Sickle cell disease $[2,3]$

9. Liver diseases $[2,3]$ such as acute and chronic viral hepatitis, alcoholic hepatitis, subacute, fulminant hepatic failure [2] and cirrhosis $[2,28]$

\section{Chronic renal diseases $[2,3,28]$}

11. Malignancies [3,28] and chronic debilitating conditions [3]

12. Pancreatic exocrine dysfunction $[2,28,52]$

13. Excessive sweating in hot tropical climates [2]

14. Zn depletion secondary to trauma, major surgeries, burns, blood loss, severe ischemia, and severe infections [2]

15. Oldness, secondary to the nutrient deficiencies due to physiologic, social and economic circumstances, dysfunctions influencing the intracellular availability of $\mathrm{Zn}$ ion [2,53], and achlorhydria [2]

16. Prematurity, due to a combination of a low $\mathrm{Zn}$ stores, an increased $\mathrm{Zn}$ requirement $[10,51,54,55]$, poor intestinal absorption $[10,51,55]$, and increased intestinal secretion from inflamed gut mucosa $[10,51]$

17. Eating disorders including anorexia nervosa and bulimia nervosa, in which the cutaneous manifestations are related to starvation, vomiting, abuse of drugs (such as laxatives and diuretics), and psychiatric morbidity $[56,52]$

18. Increased use of diuretics [2]

19. Trace element replacements with heavy metals [34,57]

20. Decreased $\mathrm{Zn}$ levels in maternal breast milk, which can cause its deficiency in healthy, full-term, breast fed infants [51]

\section{Conditions resulting from zinc excess}

The elemental $\mathrm{Zn}$ in pharmacological doses of 4 to $12 \mathrm{mg} / \mathrm{kg} /$ day can result in manifestations of $\mathrm{Zn}$ excess including gastroenteritis, gastrointestinal bleeding, microcytosis, relative neutropenia, hypoceruloplasminemia, and in prolonged cases, anemia secondary to $\mathrm{Cu}$ deficiency. In the cases of $\mathrm{Cu}$ deficiency anemia, withdrawing $\mathrm{Zn}$ can improve the anemia $[28,58]$.

\section{Manifestations of zinc deficiency in humans}

Although many human body organs are affected by severe $\mathrm{Zn}$ deficiency, such as the immune, central nervous, gastrointestinal, reproductive, integumentary and reproductive systems [2], the skin is commonly involved and is often one of the first organs affected by this deficiency [3].
The skin involvement is in the form of erythematous rashes, scaly plaques, and ulcers on the acral and periorificial areas, known as acrodermatitis [3,59]. Indeed, both congenital and acquired $\mathrm{Zn}$ deficiencies are usually expressed as a variety of skin manifestations including AE, psoriasis (Ps)-like eruptions, blisters, onychopathy, and hair loss [9]. In animals, similar conditions have been reported. For example, a rare genetic form of $\mathrm{Zn}$ deficiency can cause acrodermatitis in bull terriers, which does not respond to the $\mathrm{Zn}$ supplementation and is invariably fatal. In this disorder, a defect in $\mathrm{Zn}$ utilization or uptake at a cellular level has been hypothesized [45].

Marginal $\mathrm{Zn}$ deficiency can be considered as a silent factor in the pathogenesis of different systemic and skin diseases, abnormal lymphocytic functions, enhanced susceptibility to infections, prolonged healing, and impaired destruction of free radicals [28].

In sum, the clinical manifestations of $\mathrm{Zn}$ deficiency are described depending on the severity of this deficiency. In the moderate forms, it results in growth retardation, and hypogonadism in male adolescents, rough skin, poor appetite, neurologic dysfunction, mental lethargy, delayed healing of wound, and cell-mediated immunity dysfunction. In mild forms of $\mathrm{Zn}$ deficiency, impaired growth, decreased serum testosterone level and oligospermia in males, impairment of the immune function, hypogeusia, decreased dark adaptation, hyperammonemia, and decreased lean body mass can be seen [2].

In $\mathrm{AE}$, severe $\mathrm{Zn}$ deficiency can lead to bullous pustular dermatitis, alopecia, diarrhea, neurologic disorders, psychological impairment, weight loss, hypogonadism, prolonged and severe infections due to cellmediated immunity dysfunction, delayed ulcer healing, and in severe cases, death [2]. In this disorder, thymic atrophy is a consequence; hence, thymocytes and immune cell functions are deprived [28].

$\mathrm{Zn}$ deficiency can result in the impaired liver function and regeneration $[2,60]$. Additionally, hepatic encephalopathy due to the liver failure is associated with the Zn deficiency [2].

It is important to mention that clinical manifestations resembling $\mathrm{AE}$ have been reported in several other nutritional deficiency states such as essential fatty acid, protein and amino acid deficiencies [10].

\section{Manifestations of the zinc excess in humans}

$\mathrm{Zn}$ is non-toxic even at high concentrations [10], but $\mathrm{Cu}$ and iron deficiencies, anemia and growth retardation have been reported in the case of very high $\mathrm{Zn}$ intakes [2].

\section{Evaluation of zinc status in humans}

Measuring $\mathrm{Zn}$ in the serum as an index of the nutritional $\mathrm{Zn}$ status is problematic, because only $0.1 \%$ of its stores in the body are contained in the circulation [2]. Additionally, sample collection and laboratory techniques are important for assessing serum Zn. For example, contamination with environmental $\mathrm{Zn}$ or in test tubes can cause bias [28].

Serum $\mathrm{Zn}$ levels are subject to diurnal variation and can be influenced by the fasting status [2,5,28]. Hence, a morning fast is recommended for exact values [28]. They may be lowered by hypoalbuminemia, infection, pregnancy, acute stress, and use of oral contraceptive agents $[2,5]$. In addition, the time between the blood collection and separation of serum influences the $\mathrm{Zn}$ concentration, so that if not separated within the first 2 hours, it can lead to increase by $6 \%$ in the $\mathrm{Zn}$ concentration. Using stainless still needles vacuum tubes and anticoagulant agents without $\mathrm{Zn}$, avoiding contact with rubber 
taps and hemolysis, and separating the plasma or serum within 45 minutes prevent bias in the serum $\mathrm{Zn}$ assessment [28].

Normal plasma Zn levels are 10-15 $\mu \mathrm{mol} / 1$ [2] or 70-110 $\mu \mathrm{g} / \mathrm{dl}$. The activity of serum alkaline phosphatase is moderately sensitive indicator of the $\mathrm{Zn}$ status because its activity remains close to normal unless there is excessive and prolonged deficiency [28].

\section{Treatment with zinc supplements}

In a review article, Bibi Nitzan and Cohen commented that the success rates for treatment with $\mathrm{Zn}$ vary depending on the disease, mode of application and the kind of $\mathrm{Zn}$ salt used. From their view point, alternative modes of treatment are superior to $\mathrm{Zn}$ itself [61].

Oral $\mathrm{Zn}$ can be administered as acetate, gluconate or sulphate. It seems that the sulphate form is better tolerated. It is estimated that one $100 \mathrm{mg}$ capsule of the $\mathrm{Zn}$ sulphate has $22.5 \mathrm{mg}$ of the elemental $\mathrm{Zn}$ [28].

The elemental $\mathrm{Zn}$ in the dose of $2.5 \mathrm{mg} / \mathrm{kg} /$ day (maximum 150 $\mathrm{mg} /$ day) is safe $[28,58]$. Its requirement is particularly high in young and premature infant to increase the rate of growth and cognitive development [10,51]. The American Society for Clinical Nutrition recommends that the premature newborns should be supplemented with $\mathrm{Zn}$ at the dose of $400 \mu \mathrm{g} / \mathrm{kg} /$ day [62].

- $\quad Z n$ supplementation can be used as adjunctive treatment in many diseases [2]. The following has been summarized for some of these disorders:

- $\quad$ Zn supplementations significantly decrease the morbidity and mortality from acute infections and shorten the recovery time. They reduce the incidence of acute lower respiratory infection and diarrhea especially in the infants and young children [2].

- Supplementations of $\mathrm{Zn}$ improve wound healing and increase resistance to infections in elderly people $[2,63]$.

- They probably are effective in preventing cancer induction by decreasing oxidative stress and improving immunity functions $[2,60]$.

- In animals, it has been shown that $\mathrm{Zn}$ supplementation may prevent both acute and chronic alcohol- induced liver injuries [2].

- They are effective in improving the psychometric performance in encephalopathic patients with cirrhosis $[2,64]$

- $\quad$ Early Zn supplementation in low birth-weight or small-forgestational-age infants can result in the improvement of growth [10].

\section{Side effects of zinc and ways for its prevention and treatment}

Elemental $\mathrm{Zn}$ is safe in the dose of $2.5 \mathrm{mg} / \mathrm{kg} /$ day (maximum $150 \mathrm{mg} /$ day) $[28,58]$. Tolerance at the usual dosage is good [8]. The WHO- recommended intake of $\mathrm{Zn}$ is $10-15 \mathrm{mg}$ for adults and $5 \mathrm{mg}$ for infants. This value will be changed dependent upon physiologic states such as pregnancy and lactation and in pathologic states such as inflammatory bowel disease, bums, cirrhosis of liver, chronic infections, cystic fibrosis and in patients under treatment with longterm hemodialysis, chelating agents and total parenteral nutrition. The amount of $\mathrm{Zn}$ should be expressed as the elemental amount, for example, $5 \mathrm{mg}$ of the $\mathrm{Zn}$ sulphate has approximately $1 \mathrm{mg}$ of the elemental $\mathrm{Zn}$ [46].

Nausea, vomiting, diarrhea, and temporary pruritus have been described as side effects of oral $\mathrm{Zn}$ supplementation [28,58], which are fleeting and dose dependent [8]. It appears that nausea is the most prevalent side effect of the oral $\mathrm{Zn}$. The severity of these side effects can be reduced by dividing the total dose into three daily doses to be taken with the meals [28].

Although $\mathrm{Zn}$ toxicity is very low, high doses during chronic administration can lead to the marked risk of hypocupremia [8]. Elemental $\mathrm{Zn}$ in pharmacological doses of 4 to $12 \mathrm{mg} / \mathrm{kg} / \mathrm{day}$ can result in gastroenteritis, gastrointestinal bleeding, microcytosis, relative neutropenia, hypoceruloplasminemia, and in prolonged use, anemia secondary to $\mathrm{Cu}$ deficiency $[28,58]$. Fever, malaise, dizziness, headaches, anemia and even death are seen in cases of overdose [46].

$\mathrm{Zn}$ supplementations are not appropriate for the patients with AIDS and diabetes mellitus type 1, because they increase morbidity and deteriorate glucose metabolism, respectively $[2,65] . \mathrm{Zn}$ is not teratogenic, so it can be prescribed during pregnancy [8]. $\mathrm{Zn}$ administered in dental restoration can cause oral LP, palmoplantar pustulosis, a maculopapular rash, and systemic contact dermatitis [19]. For the first time, Ito et al reported disseminated LP due to the zinc chloride present in the metallic dental crown in a 62-year-old- woman [66].

$\mathrm{Zn}$ supplementations can reduce the absorption of iron, tetracycline, penicillamine and quinolone [28].

\section{Conclusion}

$\mathrm{Zn}$ is an essential metal for normal cellular functions [9]. It can be used as an effective agent for the treatment of some skin and hair disorders, but generally, it seems that with the exception of the states relating to $\mathrm{Zn}$ deficiency, there is very little evidence to support the efficacy of $\mathrm{Zn}$ as a first-line treatment for many disorders [61].

\section{Acknowledgment}

We thank Prof. Gino A. Vena, Dr. Jim Schwartz, Prof. Hee Chul Eun, Dr. Jouni Uitto, Dr. Yutaka Hatano, Dr. Craig N Burkhart, Dr. Khalifa E.Sharquie, Dr. Sébastien Barbarot, Prof. Ulrike Raap, Sabrina Campagnolo, Dr. Joanna Wallengren, Dr. Renata Strumia, and Dr. Janice Cameron. They supported us by sending their invaluable manuscripts.

\section{References}

1. Bagherani N, Yaghoobi R, Omidian M (2011) Hypothesis: zinc can be effective in treatment of vitiligo. Indian J Dermatol 56: 480-484. [Crossref]

2. Tuerk MJ, Fazel N (2009) Zinc deficiency. Curr Opin Gastroenterol 25: 136-143. [Crossref]

3. Kawamura T, Ogawa Y, Nakamura Y, Nakamizo S, Ohta Y, et al. (2012) Severe dermatitis with loss of epidermal Langerhans cells in human and mouse zinc deficiency. J Clin Invest 122: 722-732. [Crossref]

4. Wuehler SE, Peerson JM, Brown KH (2005) Use of national food balance data to estimate the adequacy of zinc in national food supplies: methodology and regional estimates. Public Health Nutr 8: 812-819. [Crossref]

5. Pilch SM, Senti FR (1985) Analysis of zinc data from the second National Health and Nutrition Examination Survey (NHANES II). J Nutr 115: 1393-1397. [Crossref]

6. Wakimoto P, Block G (2001) Dietary intake, dietary patterns, and changes with age: an epidemiological perspective. J Gerontol A Biol Sci Med Sci 56 Spec No 2: 65-80. [Crossref]

7. Patel GK1 (2005) The role of nutrition in the management of lower extremity wounds. Int J Low Extrem Wounds 4: 12-22. [Crossref]

8. Stéphan F, Revuz J (2004) Zinc salts in dermatology. Ann Dermatol Venereol 131 455-460. [Crossref]

9. Park H, Kim CW, Kim SS, Park CW (2009) The therapeutic effect and the changed 
serum zinc level after zinc supplementation in alopecia areata patients who had a low serum zinc level. Ann Dermatol 21: 142-146. [Crossref]

10. Barbarot S, Chantier E, Kuster A, Hello M, Roze JC, et al. (2010) Symptomatic acquired zinc deficiency in at-risk premature infants: high dose preventive supplementation is necessary. Pediatr Dermatol 27: 380-383. [Crossref]

11. Henkel R, Baldauf C, Schill WB (2003) Resorption of the element zinc from spermatozoa by the epididymal epithelium. Reprod Domest Anim 38: 97-101. [Crossref]

12. Henkel RR, Defosse K, Koyro HW, Weissmann N, Schill WB (2003) Estimate of oxygen consumption and intracellular zinc concentration of human spermatozoa in relation to motility. Asian J Androl 5: 3-8. [Crossref]

13. Henkel R, Bittner J, Weber R, Hüther F, Miska W (1999) Relevance of zinc in human sperm flagella and its relation to motility. Fertil Steril 71: 1138-1143. [Crossref]

14. Kappus H, Reinhold C (1994) Heavy metal-induced cytotoxicity to cultured human epidermal keratinocytes and effects of antioxidants. Toxicol Lett 71: 105-109. [Crossref]

15. Grungreiff K (2002) Zinc in liver disease. The Journal of Trace Elements in Experimental Medicine 15: 67-78.

16. Sharquie KE, Najim RA, Al-Hayani RK, Al-Nuaimy AA, Maroof DM (2008) The therapeutic and prophylactic role of oral zinc sulfate in management of recurrent aphthous stomatitis (ras) in comparison with dapsone. Saudi Med J 29: 734-738. [Crossref]

17. Akiyama H, Yamasaki O, Tada J, Arata J (1999) Calcium oxide and magnesium oxide inhibit plasma coagulation by Staphylococcus aureus cells at the lower concentration than zinc oxide. J Dermatol Sci 22: 62-65. [Crossref]

18. Akiyama H, Yamasaki O, Kanzaki H, Tada J, Arata J (1998) Effects of zinc oxide on the attachment of Staphylococcus aureus strains. J Dermatol Sci 17: 67-74. [Crossref]

19. Yoshihisa Y, Shimizu T (2012) Metal allergy and systemic contact dermatitis: an overview. Dermatol Res Pract: 749561.

20. Yamaoka J, Kume T, Akaike A, Miyachi Y (2000) Suppressive effect of zinc ion on iNOS expression induced by interferon-gamma or tumor necrosis factor-alpha in murine keratinocytes. J Dermatol Sci 23: 27-35. [Crossref]

21. Tsuda T, Markova D, Wang H, Evangelisti L, Pan TC, et al. (2004) Zinc finger protein $\mathrm{Zac} 1$ is expressed in chondrogenic sites of the mouse. Dev Dyn 229: 340-348. [Crossref]

22. Tseng H (1998) Basonuclin, a zinc finger protein associated with epithelial expansion and proliferation. Front Biosci 3: D985-988. [Crossref]

23. Mahoney MG, Tang W, Xiang MM, Moss SB, Gerton GL, et al. (1998) Translocation of the zinc finger protein basonuclin from the mouse germ cell nucleus to the midpiece of the spermatozoon during spermiogenesis. Biol Reprod 59: 388-394.

24. Impola U, Toriseva M, Suomela S, Jeskanen L, Hieta N, et al. (2003) Matrix metalloproteinase-19 is expressed by proliferating epithelium but disappears with neoplastic dedifferentiation. Int J Cancer 103: 709-716. [Crossref]

25. Maret W (2003) Cellular zinc and redox states converge in the metallothionein/thionein pair. J Nutr 133: 1460S-1462S. [Crossref]

26. Theocharis SE, Margeli AP, Koutselinis A (2003) Metallothionein: a multifunctional protein from toxicity to cancer. Int J Biol Markers 18: 162-169. [Crossref]

27. Theocharis SE, Margeli AP, Klijanienko JT, Kouraklis GP (2004) Metallothionein expression in human neoplasia. Histopathology 45: 103-118. [Crossref]

28. Stefani M, Bottino G, Fontenelle E, Azulay DR (2009) Efficacy comparison between cimetidine and zinc sulphate in the treatment of multiple and recalcitrant warts. An Bras Dermatol 84: 23-29. [Crossref]

29. Bray TM, Bettger WJ (1990) The physiological role of zinc as an antioxidant. Free Radic Biol Med 8: 281-291. [Crossref]

30. Palmiter RD, Cole TB, Findley SD (1996) ZnT-, a mammalian protein that confers resistance to zinc by facilitating vesicular sequestration. EMBO $J$ 15: 1784-1791. [Crossref]

31. Yanagi T, Kodama K, Yoshihisa Y, Shimizu H, Shimizu T (2006) Macrophage migration inhibitory factor in zinc-allergic systemic contact dermatitis. Cytokine 35: 270-274. [Crossref]

32. Guéniche A, Viac J, Lizard G, Charveron M, Schmitt D (1995) Protective effect of zinc on keratinocyte activation markers induced by interferon or nickel. Acta Derm Venereol 75: 19-23. [Crossref]

33. Jarrousse V, Castex-Rizzi N, Khammari A, Charveron M, Dréno B (2007) Zinc salts inhibit in vitro Toll-like receptor 2 surface expression by keratinocytes. Eur J Dermatol 17: 492-496. [Crossref]

34. Bhat YJ, Manzoor S, Khan AR, Qayoom S (2009) Trace element levels in alopecia areata. Indian J Dermatol Venereol Leprol 75: 29-31. [Crossref]

35. Biyukavir M, Gurol A, Karabulut A, Budak G, Karaem M (2005) The role of iron and zinc in chemotherapy induced alopecia. J Quantitative Spectroscopy Radiative Transfer 95: 256-261.

36. Plonka PM, Handjiski B, Popik M, Michalczyk D, Paus R (2005) Zinc as an ambivalent but potent modulator of murine hair growth in vivo- preliminary observations. Exp Dermatol 14: 844-853. [Crossref]

37. Lee SY, Nam KS, Seo YW, Lee JS, Chung H (1997) Analysis of serum zinc and copper levels in alopecia areata. Ann Dermato 9: 239-241. [Crossref]

38. Chodorowska G, Lecewicz-Torun B, Wiercinski J (1990) Study of the zinc content of hair and serum in selected skin diseases. Ann Univ Mariae Curie Sklodowska Med 45 199-205. [Crossref]

39. Yaghoobi R, Omidian M, Bagherani N (2011) Comparison of therapeutic efficacy of topical corticosteroid and oral zinc sulfate-topical corticosteroid combination in the treatment of vitiligo patients: a clinical trial. BMC Dermatology 11: 7.

40. Plonka PM, Handjiski B, Michalczyk D, Popik M, Paus R (2006) Oral zinc sulphate causes murine hair hypopigmentation and is a potent inhibitor of eumelanogenesis in vivo. Br J Dermatol 155: 39-49. [Crossref]

41. Tasaki M, Hanada K, Hashimoto I (1993) Analyses of serum copper and zinc levels and copper/zinc ratios in skin diseases. J Dermatol 20: 21-24. [Crossref]

42. Anavekar NS, Williams R, Chong AH (2007) Facial Sweet's syndrome mimicking rosacea fulminans. Australas J Dermatol 48: 50-53. [Crossref]

43. Palit A, Inamadar AC (2004) Periorificial dermatitis with dramatic response to zinc Arch Dis Child 89: 501. [Crossref]

44. Nacken W, Mooren FC, Manitz MP, Bode G, Sorg C, et al. (2005) S100A9 deficiency alters adenosine-5'-triphosphate induced calcium signalling but does not generally interfere with calcium and zinc homeostasis in murine neutrophils. Int J Biochem Cell Biol 37: 1241-1253. [Crossref]

45. Hall J1 (2005) Diagnostic dermatology. Zinc responsive dermatosis. Can Vet J 46: 555557. [Crossref]

46. Abramovits W (1979) Dermatology-epitomes of progress: a capsule on zinc. West $J$ Med 130: 165-166. [Crossref]

47. Pirot F, Millet J, Kalia YN, Humbert P (1996) In vitro study of percutaneous absorption, cutaneous bioavailability and bioequivalence of zinc and copper from five topical formulations. Skin Pharmacol 9: 259-269. [Crossref]

48. Pirot F, Panisset F, Agache P, Humbert P (1996) Simultaneous absorption of copper and zinc through human skin in vitro: influence of counter-ion and vehicle. Skin Pharmacol 9: 43-52. [Crossref]

49. King JC, Shames DM, Woodhouse LR (2000) Zinc homeostasis in humans. J Nutr 130 1360S-1366S. [Crossref]

50. Maverakis E, Fung MA, Lynch PJ, Draznin M, Michael DJ, et al. (2007) Acrodermatitis enteropathica and an overview of zinc metabolism. J Am Acad Dermatol 56: 116-124. [Crossref]

51. Haliasos EC, Litwack P, Kristal L, Chawla A (2007) Acquired zinc deficiency in full-term newborns from decreased zinc content in breast milk. Cutis 79: 425-428. [Crossref]

52. Goskowicz M, Eichenfield LF (1993) Cutaneous findings of nutritional deficiencies in children. Curr Opin Pediatr 5: 441-445. [Crossref]

53. Mocchegiani E, Bertoni-Freddari C, Marcellini F, Malavolta M (2005) Brain, aging and neurodegeneration: role of zinc ion availability. Prog Neurobiol 75: 367-390. [Crossref]

54. Coelho S, Fernandes B, Rodrigues F, Reis JP, Moreno A, et al. (2006) Transient zinc deficiency in a breast fed, premature infant. Eur J Dermatol 16: 193-195. [Crossref]

55. Kuramoto Y, Igarashi Y, Tagami H (1991) Acquired zinc deficiency in breast-fed infants. Semin Dermatol 10: 309-312. [Crossref]

56. Strumia R (2005) Dermatologic signs in patients with eating disorders. Am J Clin Dermatol 6: 165-173. [Crossref]

57. Naginiene R, Kregzdyte R, Abdrakhmanovas A, Ryselis S (2004) Assay of trce elements, thyroid gland and blood indices in children with alopecia. Trace Elements and Electrolytes 21: 207-210. 
58. Al-Gurairi FT, Al-Waiz M, Sharquie KE (2002) Oral zinc sulphate in the treatment of recalcitrant viral warts: randomized placebo-controlled clinical trial. $\mathrm{Br} J$ Dermatol 146: 423-431. [Crossref]

59. Cohen JB, Janniger CK, Piela Z, Szepietowski JC, Samady JA, et al. (1999) Dermatologic correlates of selected metabolic events. J Med 30: 149-156. [Crossref]

60. Prasad AS, Kucuk O (2002) Zinc in cancer prevention. Cancer Metastasis Rev 21: 291-295. [Crossref]

61. Bibi Nitzan Y, Cohen AD (2006) Zinc in skin pathology and care. $J$ Dermatolog Treat 17: 205-210. [Crossref]

62. Greene HL, Hambidge KM, Schanler R, Tsang RC (1988) Guidelines for the use of vitamins, trace elements, calcium, magnesium, and phosphorus in infant and children receiving total parenteral nutrition: report of the Subcommittee on Pediatric Parenteral
Nutrient Requirements from the Committee on Clinical Practice Issues of the American Society for Clinical Nutrition. Am J Clin Nutr 48: 1324-1342. [Crossref]

63. Sandstead HH (1994) Understanding zinc: recent observations and interpretations. $J$ Lab Clin Med 124: 322-327. [Crossref]

64. Reding P, Duchateau J, Bataille C (1984) Oral zinc supplementation improves hepatic encephalopathy. Results of a randomised controlled trial. Lancet 2: 493-495. [Crossref]

65. Overbeck S, Rink L, Haase H (2008) Modulating the immune response by oral zinc supplementation: a single approach for multiple diseases. Arch Immunol Ther Exp (Warsz) 56: 15-30. [Crossref]

66. Ito Y, Saito K, Hatano Y, Goto M, Takahashi A, et al. (2012) Disseminated lichen planus due to a zinc allergy. $J$ Dermatol 39: 948-949. [Crossref]

Copyright: $(02016$ Bagherani N. This is an open-access article distributed under the terms of the Creative Commons Attribution License, which permits unrestricted use, distribution, and reproduction in any medium, provided the original author and source are credited. 